\title{
Improving durum wheat (Triticum turgidum L. var durum) grain yellow pigment content through plant breeding
}

\author{
Albert Schulthess, and Andrés R. Schwember \\ Facultad de Agronomía e Ingeniería Forestal, Pontificia Universidad Católica de Chile, Ave. Vicuña \\ Mackenna 4860, Macul, Santiago, Chile.
}

\begin{abstract}
A. Schulthess, and A.R. Schwember. 2013. Improving durum wheat (Triticum turgidum L. var durum) grain yellow pigment content through plant breeding. Cien Inv. 40(3): 475-490. Wheat grain yellow pigment content (GYPC) is an important trait that determines pasta quality. The main objective of this review is to examine the genetics regulating GYPC to enhance it through breeding, leading to improved pasta quality. Although GYPC is a polygenic trait, its high heritability has facilitated breeding internationally. GYPC is influenced by one or two major loci with additive effects plus several minor genes, and there is evidence showing that the phytoene synthase loci $P S Y 1 A$ and $P S Y 1 B$ are strong candidate genes that regulate GYPC. Nine Chilean durum wheat (Triticum turgidum L. var. durum) genotypes showed intermediate to low levels of GYPC based upon both phenotypic and genotypic data. The next step is to improve GYPC in those materials by introgressing the high-yellowness PSY1 allelic variants (i.e., the $P S Y 1 A o$ allele and the PSY1Bb allele) using plant breeding strategies such as backcrossing and marker-assisted selection.
\end{abstract}

Key words: durum wheat, grain yellow pigment content, improved color, PSY1A, PSY1B, backcrossing, marker-assisted selection.

\section{Introduction}

Durum wheat (Triticum turgidum L. var. durum) is the only tetraploid species of wheat of commercial importance that is widely cultivated today (Blanco et al., 1998; Shewry, 2009). It is used in different parts of the world for several food products, such as pasta, couscous, unleavened bread, bulgur, and mote, among others (Nachit, 1992). However, the main use of durum wheat is pasta making because of its high protein content

Received April 18, 2013. Accepted October 10, 2013. Corresponding author: aschwember@uc.cl and vitreousness (Troccoli et al., 2000; Ficco et al., 2009). It has been postulated that this type of wheat was developed by artificial selection of the domesticated emmer wheat strains formerly grown in Central Europe and the Near East around 7000 B.C., which developed a naked, free-threshing form (Zohary and Hopf, 1993). In contrast to common (bread) wheat (Triticum aestivum L.), which after grinding produces particles of flour smaller than $212 \mu \mathrm{m}$ (Mellado, 2007), durum wheat milling produces a coarse particle called semolina that it is used for pasta production (Sissons, 2008) and whose particle size ranges between 125 and 355 $\mu \mathrm{m}$ (Mellado, 2007). Furthermore, its intense 
semolina yellow color (Kneipp, 2008), high protein content, gluten content, and strength make durum wheat ideal for pasta making purposes (Harlan, 1995).

In general, there is a positive correlation between high semolina yellowness and pasta quality (Borrelli et al., 2003). Pasta color is highly associated with the consumer's choice, and the competition in the pasta market has made this trait even more important (Dexter and Marchylo, 2001), especially after the legal ban of the use of artificial coloring in pasta production in certain countries in Europe (Hare, 2006). Pasta color essentially depends on the combination of semolina yellowness and brownness (Porceddu, 1995). The desirable yellowness of pasta and semolina comes mostly from carotenoid pigments (Borrelli et al., 2008), mainly trans-lutein at the semolina level (Hentschel et al., 2002; Ramachandran et al., 2010), and their oxidative degradation (Borrelli et al., 2008). Two groups of objective methods are used for the evaluation of the yellow color of pasta, flour or semolina from wheat. The first group of methods is based upon the extraction of pigments using $n$-butanol followed by the estimation of their concentrations using spectrophotometry techniques such as the standard 14-50 method (AACC, 1995) or the ICC 152 method (Hentschel et al., 2002). The second method relies on a reflectance colorimeter for recording the $\mathrm{b}^{*}$ value (Digesù et al., 2009), which denotes yellowness when positive (Feillet et al., 2000).

The main objective of this review is to examine the genetics regulating the endosperm yellowness with the aim of improving grain yellow pigment content (GYPC) and pasta quality through durum wheat breeding.

\section{Desirable traits and Chilean institutions involved in durum wheat breeding}

The superior cultivars of durum wheat encompass traits such as high semolina yellowness, high grain protein content, pasta firmness, and minimal cooking loss (Troccoli et al., 2000; Sissons et al., 2005). The yellow color is also desired for the yellow alkaline noodles that are made from common wheat (Mares and Campbell, 2001) and consumed in Japan and southeastern Asia, in which GYPC contributes significantly to their color (Fu, 2008). In this sense, wheat lines for these products need higher GYPC (Kruger et al., 1992). Conversely, lower GYPC values are preferred for Chinese-style foods such as steamed bread and Chinese noodles made from common wheat (He et al., 2004; Fu, 2008) because these products require a bright white to creamy flour color (Mares and Campbell, 2001).

In Chile, the INIA (Instituto de Investigaciones Agropecuarias) is the institution that has carried out most of the durum wheat breeding activities nationally, and it has launched fifteen cultivars of durum wheat between 1956 and 2002, covering approximately $90 \%$ of the national crop surface (Matus, 2007). To avoid using artificial coloring, improving the content and the quality of GYPC is an essential and central topic related to future plant breeding programs of durum wheat that would benefit both the consumers and the national pasta industry (Schulthess, 2013). One of the INIA main objectives in the medium and long term is to improve the semolina yellowness of durum wheat from 20 to 26 on the Minolta colorimetric scale (Matus, 2007). The second durum wheat breeding program, in order of importance, is associated with the Pontificia Universidad Católica de Chile (PUC). This program was active between 1972 and 2008 and then was resumed in 2010. It has launched over ten cultivars of durum wheat, common wheat and triticale, based primarily on materials introduced from Mexico belonging to the Centro Internacional de Mejoramiento de Maíz y Trigo (CIMMYT). This program has relied on hybridizations and selections that have been made in Chile, and Ambra UC and Brescia UC are durum wheat cultivars that continue to be used by growers (Schwember, 2012). 
There have been no breeding efforts for improving the semolina color in Chile until recently, which is evidenced by the medium to low GYPC levels of nine Chilean genotypes (eight cultivars plus one advanced breeding line) compared to the values of other durum and common wheat materials bred in North America and Australia (Schulthess, 2013) (Figure 1).

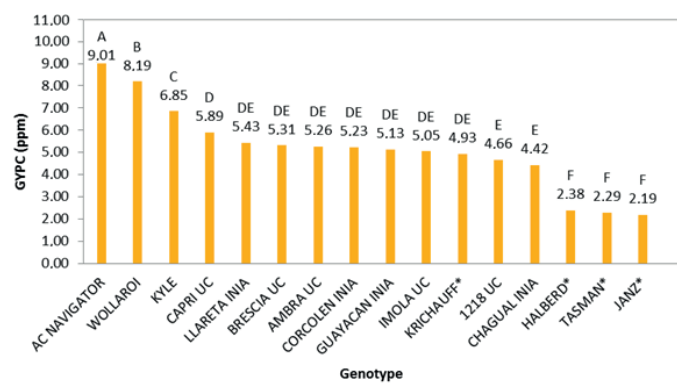

Figure 1. Grain yellow pigment content (GYPC) (ppm) values of the eight main durum wheat Chilean cultivars, Chagual INIA, Corcolén INIA, Guayacán INIA, Llareta INIA, Ambra UC, Brescia UC, Capri UC, and Imola UC and the advanced breeding line 1218 UC showed intermediate to low levels of semolina yellowness relative to other elite international genotypes (AC Navigator, Wollaroi and Kyle) cultivated under the same environmental conditions. GYPC was determined by spectrophotometry as described by Zhang and Dubcovsky (2008), and three replicates per genotype were averaged. Genotypes that share letters are not significantly different from each other with $95 \%$ confidence based on the Student-Newman-Keuls (SNK) test. Asterisks indicate common wheat cultivars (Schulthess, 2013).

\section{Carotenoids and the genetic control of endosperm yellowness}

The carotenoid pigment family comprises more than 750 members that are present in plants, bacteria and fungi and constitutes the second most abundant class of naturally occurring pigments (Britton, 1998; DellaPenna and Pogson, 2006). All carotenoids are derived from phytoene, and most of them are $\mathrm{C}_{40}$ polyenes. They play a crucial role in photosynthesis, being required for the correct assembly of the photosystems and light-harvesting complexes, and as photoprotective compounds by limiting oxidative damage (Demmig-Adams and Adams, 1996; Yamamoto et al., 1999; Cuttriss et al., 2006). In addition to their photosynthetic functions, carotenoids are involved in plant reproduction through their color and natural aromas attracting birds and insects. They are also essential components of the human diet because $\beta$-carotene is a precursor to vitamin A (Yeum and Russell, 2002), and lutein and zeaxanthin have been associated with the prevention of age-related macular degeneration and cataracts (Landrum and Bone, 2004). Vitamin A deficiency, a major problem in parts of the developing world, can result in permanent blindness and increased susceptibility to infectious diseases (West and Darnton-Hill, 2001).

There has been an increasing focus to study carotenoids in non-green tissues, particularly in grains produced by staple food crops such as cereals (Howitt and Pogson, 2006). The majority of the research has been conducted in maize, as the grains contain high levels of carotenoids, and mutants are readily available (Howitt et al., 2009). Research has focused on increasing the carotenoid content of maize or changing the relative proportion of various carotenoids within the grain through conventional breeding (Harjes et al., 2008). As a result, a number of biosynthetic genes involved in carotenogenesis have been characterized (Buckner et al., 1990; Hable et al., 1998; Matthews et al., 2003; Singh et al., 2003; Gallagher et al., 2004; Li et al., 2007), and some of them are linked to quantitative trait loci (QTL) for carotenoid content (Wong et al., 2004; Chander et al., 2008; Harjes et al., 2008). Rice, which does not contain any carotenoids in the endosperm, has been genetically engineered to accumulate $\beta$-carotene in this seed tissue (Ye et al., 2000; Paine et al., 2005). In contrast, research into carotenoid biosynthesis and content in wheat endosperm is not as advanced. This reflects the complexity of wheat due to its polyploid nature, causing it to possess various homeoforms of every gene. Nonetheless, wheat is an interesting model, where an almost white endosperm still has variation in color, for which there are identified QTLs (Howitt et al., 2009). The color of the wheat endosperm is the major determinant of flour color and is primarily influenced by its 
carotenoid content (Mares and Campbell, 2001), which requires a complex metabolic pathway for synthesis, involving at least ten different enzymes (Hirschberg, 2001) (Figure 2).

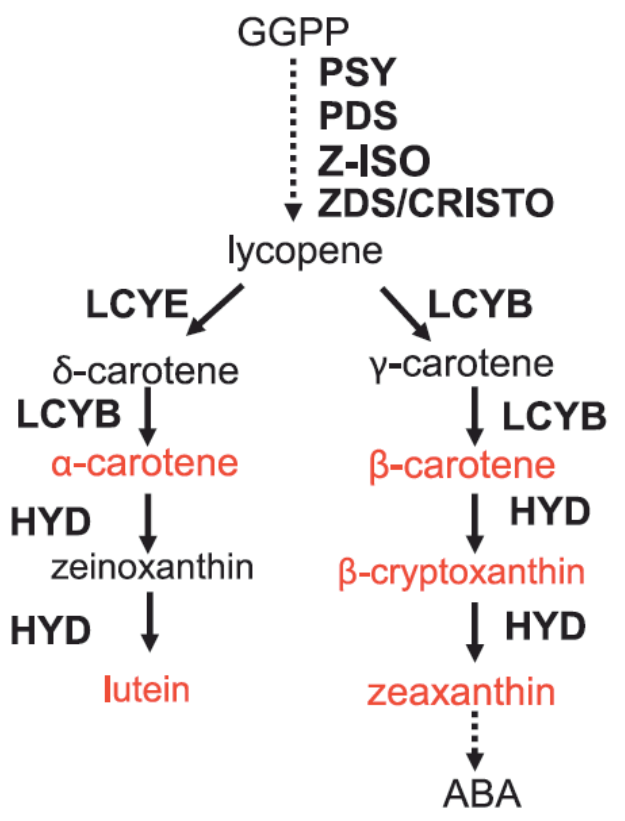

Figure 2. Summary of the synthesis of various carotenoid compounds and the enzymes involved in the pathway (Harjes et al., 2008). Abbreviations: GGPP: geranylgeranyl pyrophosphate; PSY: phytoene synthase; PDS: phytoene desaturase; Z-ISO: zeta-carotene isomerase; ZDS: zetacarotene desaturase, CRISTO: carotenoid isomerase; LCYE: lycopene epsilon cyclase; LCYB: lycopene beta cyclase; HYD: carotene hydroxylase; ABA: abscisic acid.

The main carotenoid pigment of wheat grains is lutein (Kaneko et al., 1995; Panfili et al., 2004), a compound that contributes to the organoleptic quality of pasta (yellowness) (Hentschel et al., 2002). Lutein has been used as supplement in the treatment of eye diseases and to protect visual function since the 1950s, although its nutritional function is unknown. The nutritional function of a compound refers to its essentiality in the diet and thus its capacity to prevent deficiency states. As there is no clinical condition reported in humans specifically associated with lutein deficiency, this carotenoid pigment cannot satisfy the definition of a nutrient (Granado et al., 2003). However, yellowness is a desirable trait for pasta and therefore an important target in durum wheat breeding programs. Conversely, white flour varieties are usually selected in common wheat breeding programs because yellow pigments are considered a detrimental quality for breadmaking. Consequently, both durum and common wheat breeders can benefit from a better understanding of the genetic factors controlling GYPC. Such knowledge will also be used in future attempts to engineer the nutritionally important carotenoid pathway in cereals (Zhang and Dubcovsky, 2008).

The yellow pigmentation of the endosperm is mainly controlled by additive gene effects and has high heritability in durum (Elouafi et al., 2001) and common wheat (Mares and Campbell, 2001). Multiple QTLs linked to endosperm yellowness have been reported in the literature in the last years (Table 1). Genetic studies on GYPC or endosperm yellowness have been somewhat constrained because some of the first QTLs associated with grain pigment were identified in crosses, including wild tetraploid parental lines (Joppa et al., 1997; Gonzalez-Hernandez et al., 2004), and therefore, they were thought to have limited application to modern durum wheat germplasm. However, many studies have been conducted to localize for genetic factors associated with endosperm yellowness variation in wheat (Table 1), and the results indicate that the trait is influenced by one or two major loci plus several minor genes (He et al., 2009b). Additionally, non-additive genetic effects such as epistatic interactions have also been reported for this trait in durum wheat (Zhang et al., 2008; Roncallo et al., 2012). Elouafi et al. (2001) and Pozniak et al. (2007) identified a region towards the end of chromosome 7B of durum wheat with major QTLs linked to GYPC. Zhang and Dubcovsky (2008) also reported a QTL associated with GYPC in this region linked to a SSR marker, Xgwm146, in agreement with the result reported by Pozniak et al. (2007), suggesting that the three QTLs identified in different durum wheat populations were the same locus. Similarly, GYPC-linked QTLs near the end of chromosome 7A have also been 
Table 1. Chromosome locations and reported references related to quantitative trait loci (QTL) regulating wheat endosperm yellowness (Triticum sp.) identified by linkage mapping or association mapping (Schulthess, 2013).

\begin{tabular}{|c|c|}
\hline Chromosome & References \\
\hline $1 \mathrm{~A}$ & Patil et al., 2008²; Reimer et al., 2008³; Zhang et al., 2009'; Sadeque and Turner, $2010^{1}$ \\
\hline 1B & $\begin{array}{l}\text { He } \text { et al., } 2008^{1} \text {; Reimer et al., 2008 } 2,3 \text {; Zhang et al., 2008²; Zhang et al., 2009'; Pozniak et al., 2012 2,3; } \\
\text { Roncallo et al., } 2012^{2}\end{array}$ \\
\hline $1 \mathrm{D}$ & - \\
\hline $2 \mathrm{~A}$ & $\begin{array}{l}\text { Pozniak et al., 2007²; Reimer et al., 2008 } 2,3 \text {; Blanco et al., 2011²; Pozniak et al., 20122,3; Roncallo et } \\
\text { al., } 2012^{2}\end{array}$ \\
\hline $2 \mathrm{~B}$ & Reimer et al., 2008 2,3 ; Sadeque and Turner, $2010^{1}$ \\
\hline $2 \mathrm{D}$ & Mares and Campbell, $2001^{1}$ \\
\hline $3 \mathrm{~A}$ & Parker et al., 1998'; Mares and Campbell, 2001'; Reimer et al., 2008,3 \\
\hline $3 \mathrm{~B}$ & 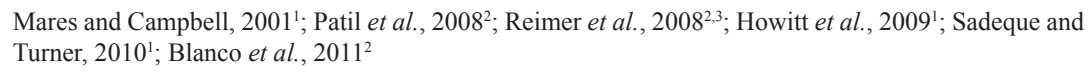 \\
\hline $3 \mathrm{D}$ & - \\
\hline $4 \mathrm{~A}$ & Reimer et al., 2008 $8^{2,3}$; Zhang et al., 2008²; Zhang et al., 2009'; Roncallo et al., $2012^{2}$ \\
\hline 4B & $\begin{array}{l}\text { Mares and Campbell, 2001'; Pozniak et al., 2007²; Reimer et al., 2008 }{ }^{2,3} \text {; Zhang et al., 2008²; Sadeque } \\
\text { and Turner, } 2010^{1}\end{array}$ \\
\hline $4 \mathrm{D}$ & - \\
\hline $5 \mathrm{~A}$ & Reimer et al., 2008 2,3 ; Blanco et al., 2011²; Roncallo et al., $2012^{2}$ \\
\hline $5 \mathrm{~B}$ & 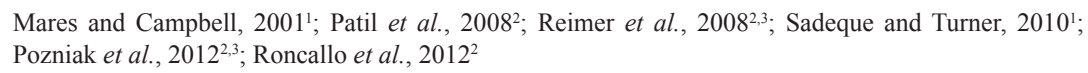 \\
\hline $5 \mathrm{D}$ & Mares and Campbell, $2001^{1}$ \\
\hline $6 \mathrm{~A}$ & $\begin{array}{l}\text { Mares and Campbell, 2001' } \text {; Reimer } \text { et al., 2008 }{ }^{2,3} \text {; Zhang et al., 2008 } \text {; Pozniak et al., 2012 }{ }^{23} \text {; Roncallo } \\
\text { et al., } 2012^{2}\end{array}$ \\
\hline $6 \mathrm{~B}$ & Pozniak et al., 2007²; Reimer et al., 2008 \\
\hline $6 \mathrm{D}$ & - \\
\hline $7 \mathrm{~A}$ & 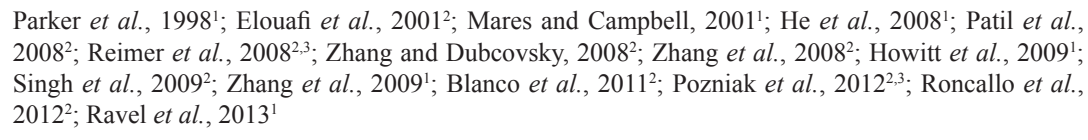 \\
\hline $7 \mathrm{~B}$ & 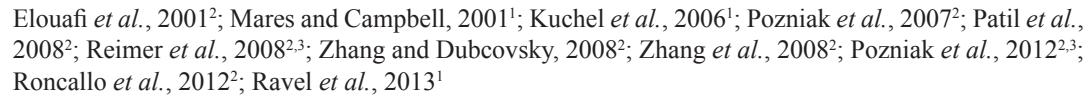 \\
\hline $7 \mathrm{D}$ & - \\
\hline
\end{tabular}

identified in durum wheat (Elouafi et al., 2001; Patil et al., 2008), which gives the chance for a homeologous copy of the QTL on chromosome 7B to exist. In addition, major QTLs on chromosomes 7A and 7B were detected in common wheat (Parker et al., 1998; Ma et al., 1999; Mares and Campbell, 2001; Kuchel et al., 2006; He et al., 2008; Zhang et al., 2009), demonstrating the importance of these two chromosomes for the endosperm yellowness.

\section{Phytoene synthase: the main candidate gene for endosperm yellowness}

The enzyme phytoene synthase (PSY) catalyzes the dimerization of two molecules of geranylgeranyl pyrophosphate into phytoene (Dogbo et al., 1988) and is considered the rate-limiting enzyme in the accumulation of carotenoids in seeds (Lindgren et al., 2003) (Figure 2). The PSY gene underwent duplication during the evolution of Angiosperm 
plants, resulting in two paralogous genes (PSY1 and PSY2) in dicotyledonous species, whereas monocotyledonous species have one additional paralogous copy, resulting in the genes PSY1, $P S Y 2$, and $P S Y 3$ in the genomes of the grass family (Dibari et al., 2012). The duplication of the $P S Y$ gene in grasses could provide finer control of carotenoid biosynthesis under different regulation scenarios. For instance, a specific mechanism could be provided to alter gene expression in the seeds without causing deleterious effects on the photosynthetic organs (Li et al., 2008). In maize, some studies showed that only PSY1 exhibited strong association with endosperm yellowness (Palaisa et al., 2003) or carotenoid content (Gallagher et al., 2004; Li et al., 2008). In agreement with this result, the homeologous copies of PSY1 were mapped within the GYPC-linked QTLs positioned on the chromosomes 7A (Singh et al., 2009) and 7B (Pozniak et al., 2007; Zhang and Dubcovsky, 2008) in durum wheat, suggesting that the genes responsible for those QTLs were the wheat PSY1 orthologues.

The PSY1 genes contain six exons and five introns in common wheat, durum wheat and related species (Wang et al., 2009), maize, rice and other grasses (genera Sorghum, Tripsacum, Zea and Coix) (Fu et al., 2009). The lengths of the exons 2, 3, 4 and 5 are perfectly conserved among the grass species, contrary to the introns, based upon sequencing the $P S Y 1$ gene in several grasses (He et al., 2008; Fu et al., 2009, He et al., 2009a; Singh et al., 2009, Wang et al., 2009). Because there is polyploidy in wheat, hexaploid (common) wheat possesses three genomes (A, B and D), while tetraploid durum wheat has two genomes (A and B), and thus three and two PSY1 homeoforms, respectively, are present in these species: PSY1A, PSY1B and PSY1D (Howitt et al., 2009).

The magnitude of the influence of the PSY1 loci on the endosperm yellowness of wheat is erratic, and this result shows how the specific experimental context of each study affects this trait (Schulthess, 2013). Thus, the percentages of explained vari- ability of endosperm yellowness for PSY1A have been low (<10\%) (Ravel et al., 2013), medium (10-30\%) (He et al., 2008; Zhang et al., 2009; Ravel et al., 2013), high (30-50\%) (Zhang et al., 2009), and very high (> 50\%) (Howitt et al., 2009) in common wheat. In parallel, the corresponding PSY1A values of the explained variation of this trait have been medium (10-30\%), high (30-50\%) and very high (> 50\%) (Blanco et al., 2011) in durum wheat. In the case of PSY1B, the percentages of explained variability of endosperm yellowness reported have been very high ( $>50 \%)$ in common wheat (Ravel et al., 2013), and low $(<10 \%)$ to medium (10-30\%) (Zhang et al., 2008; Roncallo et al., 2012) in durum wheat. The effect of the PSY1D locus on the yellowness of the endosperm has been less well studied, but recent evidence shows that it also significantly influences this trait (Ravel et al., 2013). However, the percentages of endosperm yellowness or GYPC variability explained by the PSY1 loci are not reported in several studies (Pozniak et al., 2007, Reimer et al., 2008; Zhang and Dubcovsky, 2008, He et al., 2009a; He et al. 2009b; Singh et al., 2009). Therefore, those values previously mentioned are only a partial sample of all cases in which the homeologous PSY1 loci have been studied so far (Schulthess, 2013).

With regard to the allelic variants of the PSY1 loci, the Komugi genetic resources database of wheat (Komugi, 2012) shows that eighteen, fifteen and thirteen allelic variants have been reported to date for PSY1A, PSY1B and PSY1D, respectively. In addition, phenotypic-genotypic association studies have investigated the effects of some of the PSY1 allelic variants on the endosperm yellowness using different genetic backgrounds of common and durum wheat (Table 2). One ongoing study at the PUC in collaboration with INIA-Quilamapu is currently characterizing the semolina yellowness of a durum wheat population and using molecular markers to identify PSY-1A (Singh et al., 2009) and PSY-1B (Zhang and Dubcovsky, 2008) allelic variants of those materials. Regarding PSY1A, the three allelic variants are 
PSY1Aa (1776 bp, low semolina yellowness), PSY1Al (1089 bp, intermediate yellowness), and PSY1Ao (897 bp, high yellowness) (Singh et al., 2009) (Figure 3). Concerning PSY1B, the two allelic variants correspond to $P S Y 1 B a(220 \mathrm{bp}$, lower semolina yellowness) and $P S Y 1 B b(200 \mathrm{bp}$, higher yellowness) (Reimer et al. 2008; Zhang and Dubcovsky, 2008) (Figure 4). In this work, the nine Chilean durum wheat genotypes studied exhibited the same PCR banding pattern with both the PSY1Al and PSY1Ba alleles (Figure 3 and 4), which are associated with intermediate (Singh et al., 2009) and low levels of GYPC (Reimer et al., 2008; Zhang and Dubcovsky, 2008), respectively, in agreement with the phenotypic results previously reported (Figure 1).

Table 2. Marker-phenotype association studies reporting polymorphisms within the PSY1 loci affecting endosperm yellowness of different wheat genetic backgrounds ( $\mathrm{ppm}$ : yellow pigment content; $\mathrm{b}^{*}$ : colorimetric value; $\Delta \mathrm{b}^{*}$ : colorimetric value adjusted to the value of a control genotype) (Schulthess, 2013).

\begin{tabular}{|c|c|c|c|c|}
\hline Locus & Alleles or 'haplotypes' & Genetic background & Phenotypic effect & Reference \\
\hline \multirow[t]{5}{*}{ PSY1A } & $\mathrm{a}, \mathrm{b}$ & $\begin{array}{l}217 \text { cultivars and advanced } \\
\text { lines of Chinese wheat }\end{array}$ & $\begin{array}{l}a: 1,82 \text { ppm A } \\
b: 1,30 \text { ppm B }\end{array}$ & He et al. (2008) \\
\hline & $a, b, c$ & $\begin{array}{l}342 \text { spring wheat lines } \\
\text { CIMMYT }\end{array}$ & $\begin{array}{l}a: 2,56 \mathrm{ppm} \mathrm{A} \\
b: 2,12 \text { ppm B } \\
c: \text { rare allele }\end{array}$ & He et al. (2009a) \\
\hline & $e, p, q, r, s$ & $\begin{array}{l}\text { Common wheat: Sunco, Janz, } \\
\text { Glenlea, Tasman, Cranbrook, } \\
\text { Chara, Halberd, Schomburgk, } \\
\text { Krichauff }\end{array}$ & $\begin{array}{l}e: \text { white } \\
p \text { and } q: \text { pale yellow } \\
r: \text { yellow } \\
s: \text { very yellow }\end{array}$ & $\begin{array}{l}\text { Howitt et al. } \\
(2009)\end{array}$ \\
\hline & 'p', 'jt', 'e’, 'r', 'ak', 'c' & $\begin{array}{l}372 \text { accessions of common } \\
\text { wheat from diverse origins } \\
\text { (INRA core collection) }\end{array}$ & $\begin{array}{l}\text { 'p': } 11,12 \mathrm{~b}^{*} \mathrm{~A} \\
\text { 'jt': } 11,04 \mathrm{~b}^{*} \mathrm{AB} \\
\text { 'e': } 10,89 \mathrm{~b}^{*} \mathrm{AB} \\
\text { 'r': } 10,76 \mathrm{~b}^{*} \mathrm{AB} \\
\text { 'ak': } 10,56 \mathrm{~b}^{*} \mathrm{~B} \\
\text { 'c': rare allele }\end{array}$ & Ravel et al. (2013) \\
\hline & $a, l, o$ & $\begin{array}{l}\text { Collection of } 93 \text { durum wheat } \\
\text { genotypes from diverse } \\
\text { origins }\end{array}$ & $\begin{array}{l}o: 2,2 \mathrm{ppm} \text { higher than the } l \\
\text { allele on average } \\
l: \text { at least } 2,4 \mathrm{ppm} \text { higher than } \\
\text { the } a \text { allele on average } \\
a: \text { at least } 4,6 \text { ppm lower than } \\
\text { the } o \text { allele on average }\end{array}$ & Singh et al. (2009) \\
\hline \multirow[t]{5}{*}{ PSY1B } & $a, b, c, d$ & $\begin{array}{l}217 \text { lines of Chinese winter } \\
\text { wheat }\end{array}$ & $\begin{array}{l}c: 2,01 \mathrm{ppm} \mathrm{A} \\
a: 1,71 \mathrm{ppm} \mathrm{B} \\
b: 1,40 \text { ppm C } \\
d: \text { rare allele }\end{array}$ & He et al. (2009a) \\
\hline & $\mathrm{a}, \mathrm{b}, \mathrm{d}, \mathrm{e}$ & $\begin{array}{l}342 \text { spring wheat lines } \\
\text { CIMMYT }\end{array}$ & No significant differences & He et al. (2009a) \\
\hline & $f, g$ & $\begin{array}{l}100 \text { durum wheat lines } \\
\text { CIMMYT }\end{array}$ & $\begin{array}{l}f: 1,83 \Delta \mathrm{b}^{*} \mathrm{~A} \\
g: 0,59 \Delta \mathrm{b}^{*} \mathrm{~B}\end{array}$ & He et al. (2009b) \\
\hline & 'cm', 'b', ' $a$ ', 'd' & $\begin{array}{l}372 \text { accessions of common } \\
\text { wheat from diverse origins } \\
\text { (INRA core collection) }\end{array}$ & $\begin{array}{l}\text { 'cm': } 11,16 \mathrm{~b}^{*} \mathrm{~A} \\
\text { 'b': } 10,91 \mathrm{~b}^{*} \mathrm{~B} \\
\text { 'a': } 10,56 \mathrm{~b}^{*} \mathrm{~B} \\
\text { 'd': } 10,15 \mathrm{~b} * \mathrm{C}\end{array}$ & Ravel et al. (2013) \\
\hline & $a, b$ & $\begin{array}{l}\text { Collection of } 93 \text { durum wheat } \\
\text { genotypes from diverse } \\
\text { origins }\end{array}$ & $\begin{array}{l}b: 8,96 \pm 0,39 \mathrm{ppm} \\
a: 7,59 \pm 0,19 \mathrm{ppm}\end{array}$ & $\begin{array}{l}\text { Reimer et al. } \\
(2008)\end{array}$ \\
\hline$P S Y 1 D$ & 'g', ' $a$ ' & $\begin{array}{l}372 \text { accessions of common } \\
\text { wheat from diverse origins } \\
\text { (INRA core collection) }\end{array}$ & $\begin{array}{l}\text { ' } g \text { ': } 11,37 \mathrm{~b}^{*} \mathrm{~A} \\
\text { ' } a \text { ': } 10,64 \mathrm{~b}^{*} \mathrm{~B}\end{array}$ & Ravel et al. (2013) \\
\hline
\end{tabular}




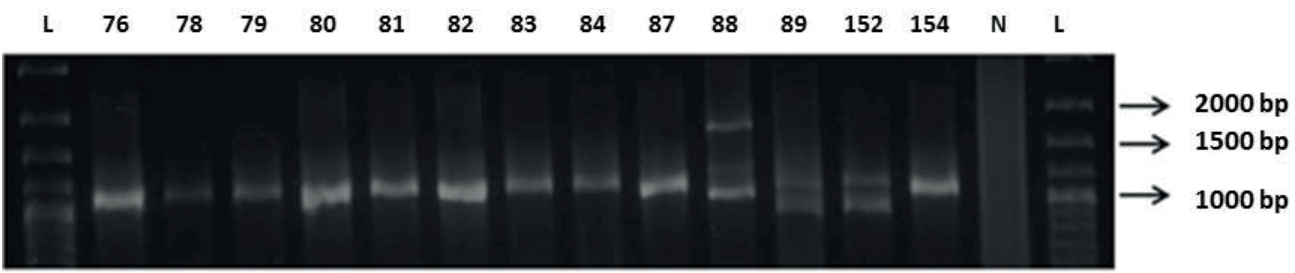

Figure 3. Allelic characterization of the PSY1A gene using the co-dominant marker Psy1-A1_STS (Singh et al., 2009) on nine Chilean genotypes (eight cultivars plus one advanced breeding line) of durum wheat. All these genotypes exhibited the PSY1Al allelic variant, previously associated with intermediate GYPC (Singh et al., 2009). Lane letters: L: GeneRuler 100 bp Plus DNA Ladder (Thermo Scientific), N: negative control. Each lane number corresponds to a genotype: UC 1113 (88) carries the PSY1Aa allele (1776 bp, low semolina yellowness). Wollaroi (89) and Commander (152) are positive controls for the PSY1Ao allele (897 bp, high yellowness), and Strongfield (154) is the positive control for the PSY1Al allele (1089 bp, intermediate yellowness) (Singh et al., 2009). The Chilean materials are the advanced breeding line 1218 UC (76) and the cultivars Ambra UC (78), Brescia UC (79), Capri UC (80), Chagual INIA (81), Corcolén INIA (82), Guayacán INIA (83), Imola UC (84) and Llareta INIA (87). The double banding pattern in the genotypes carrying alleles other than $P S Y 1 A l$ is the result of a non-specific PCR product previously described by Singh et al. (2009) (Schwember, unpublished results).

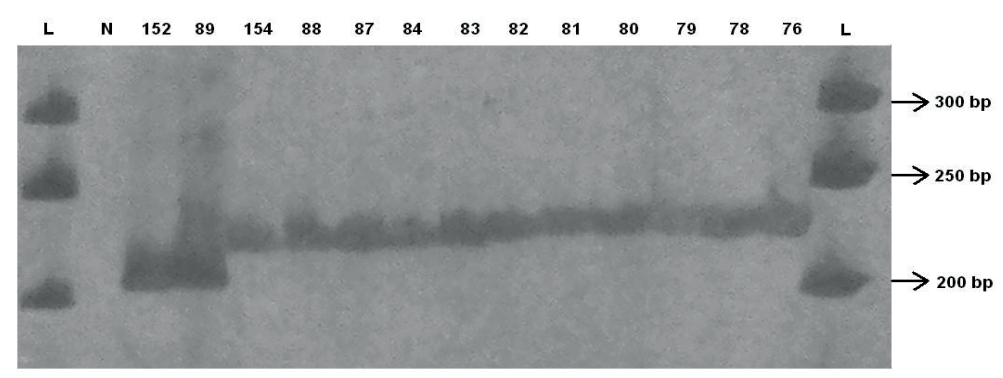

Figure 4. Allelic characterization of the $P S Y 1 B$ gene using the co-dominant marker developed by Zhang and Dubcovsky (2008) on nine Chilean genotypes, which showed exclusively the PSY1Ba allele (220 bp). Lane letters: L: O'GeneRuler 50 bp DNA Ladder (Thermo Scientific), N: negative control. Each lane number corresponds to a genotype: Commander (152) and Wollaroi (89) are positive controls for the PSY1Bb allele (200 bp, high levels of GYPC) (Reimer et al., 2008), and Strongfield (154) (Reimer et al., 2008) and UC 1113 (88) (Zhang and Dubcovsky, 2008) are positive controls for the PSY1Ba allele (220 bp, lower levels of GYPC). The Chilean materials are Llareta INIA (87), Imola UC (84), Guayacán INIA (83), Corcolén INIA (82), Chagual INIA (81), Capri UC (80), Brescia UC (79), Ambra UC (78) and 1218 UC (76) (Schwember, unpublished results).

\section{Othergenes potentially involved in determining endosperm yellowness}

Marker-phenotype associations of the PSY1 loci with endosperm yellowness are far from being perfect, sometimes resulting in unexpected values for the trait. In this regard, some studies (He et al., 2008, He et al., 2009a, He et al., 2009b) exhibited wide phenotypic variability between genotypes sharing a particular allelic variant of the $P S Y 1$ loci, which possibly reflects the polygenic nature of the endosperm yellowness observed in previous studies (Table 1). In addition, not only are there studies where the PSY1 loci explain only a small proportion of the endosperm yel- lowness variability (Zhang et al., 2008; Roncallo et al., 2012; Ravel et al., 2013), but there are also some extreme cases of no association due to the scarcity or the absence of polymorphisms in the regions studied within the sequence of PSY1A (Pozniak et al., 2007, Patil et al., 2008; Zhang and Dubcovsky, 2008, He et al., 2009b), PSY1B (Singh et al., 2009) or PSY1D (Wang et al., 2009; Ravel et al., 2013). Additionally, in other studies (see as examples Pozniak et al., 2007 and He et al., 2009a) the variation within these loci simply had no significant association with the endosperm yellowness. Moreover, Zhang and Dubcovsky (2008) raised the possibility that a second gene (or another regulatory element) is involved in control- 
ling wheat endosperm yellowness and maps very close to PSY1 on the long arm of chromosome 7. There is some evidence reported to support this idea. First, the peak of a QTL associated with GYPC identified in a population of 93 recombinant inbred lines (RILs) from the cross Kofa $\mathrm{x}$ UC1113 does not exactly match the PSY1B locus but rather matches the closely linked proximal marker Xbarc340-7B (Zhang and Dubcovsky, 2008). Second, Roncallo et al. (2012), using the same mapping population but grown in different environments in Argentina, encountered an additional QTL linked to semolina yellowness (other than the PSY1B QTL), which was located in the distal region of chromosome 7B. Third, Singh et al. (2009) and Blanco et al. (2011) reported additional QTLs influencing semolina yellowness that were positioned 23 and $26 \mathrm{cM}$ from PSY1A, respectively. Fourth, Zhang and Dubcovsky (2008) and Roncallo et al. (2012) found a QTL associated with semolina yellowness in the long arm of chromosome 7A, but the PSY1A region showed no polymorphisms between the parents of the RIL population. However, further studies are required to elucidate which specific gene (or regulatory element) is involved in GYPC in the vicinity of PSY1.

Not all the genes or the regulatory factors that affect endosperm yellowness remain anonymous. For example, another durum wheat endosperm yellowness candidate gene is $L p x-A 3$, which maps to chromosome $4 \mathrm{~A}$ and encodes a variant of lipoxygenase that has been hypothesized to be active during early developmental stages of the wheat grains (Carrera et al., 2007). Howitt et al. (2009) reported that $\varepsilon-L C Y$, which encodes a lycopene epsilon cyclase enzyme (LCYE) (Figure 2), co-localizes with a QTL positioned on chromosome 3B that influences endosperm yellowness in a double haploid $(\mathrm{DH})$ population derived from the common wheat cross Sunco $\mathrm{x}$ Tasman. Additionally, one QTL on the long arm of chromosome 2D associated with common wheat GYPC co-localizes with the TaZds-D1 locus, which encodes a zeta-carotene desaturase enzyme (ZDS) (Figure 2) (Zhang et al., 2011). More recently, two genes (each with three homeologs), HYD1 and HYD2 (Figure 2), which encode for beta-hydroxylase enzymes in wheat, were cloned and characterized. Although the developing grains showed a decreasing trend in carotenoid accumulation, the expression of HYDI, particularly $H Y D-B 1$, reached its highest levels at the last stage of tetraploid and hexaploid grain development, suggesting that carotenoids (at least xanthophylls) were still actively synthesized in mature grains. This result challenges the common perception that carotenoids are simply turned over during wheat grain development after their initial biosynthesis at the early grain development stages (Qin et al., 2012).

Despite the identification of alternative genes, several studies on candidate genes associated with endosperm yellowness agree on the important effect of the homeologous PSY1 loci on GYPC (Table 2), and they will consequently remain the principal candidate genes regulating this trait, especially in durum wheat.

\section{Transfer of QTLs or genes linked to high GYPC}

One effective breeding method for transferring or introgressing a GYPC-related QTL (or gene) in self-pollinated crops (i.e., wheat) is backcrossing (Figure 5). This method consists of transferring a specific trait governed by one or a few genes into an otherwise superior cultivar and fully recovering the recurrent parent genotype, but including the additional gene(s) controlling the desirable trait provided by the donor (nonrecurrent) parent (Briggs and Knowles, 1967). The main advantages of backcrossing are: (1) there is a high degree of genetic control during the process; thus the outcome is predictable and repeatable, (2) the previous selection gains are not lost because it is a stepwise improvement, and (3) there is no need for extensive field trials or note taking (Briggs and Knowles, 1967; Fehr, 1987). 
Conversely, the main disadvantage of backcrossing is that it does not permit the achievement of unusual combinations of genes from two or more cultivars because the effectiveness of selection decreases with an increasing number of genes under transfer (Fehr, 1987).

In marker-assisted selection (MAS), a marker (morphological, biochemical or based on DNA/ RNA variation) is used for indirect selection of a genetic determinant or determinants linked to the trait(s) of interest. Consequently, this method relies on genotypic rather than phenotypic selec- tion (Dubcovsky, 2004). MAS normally greatly increases the efficiency and effectiveness in plant breeding compared to conventional breeding methods. Once markers that are tightly linked to genes or QTLs of interest have been identified, breeders typically use specific DNA markers as a diagnostic tool to identify plants carrying the alleles of interest of these genes or QTLs (Michelmore 1995; Ribaut et al., 1997), such as the molecular markers previously mentioned for PSY1 (Zhang and Dubcovsky, 2008; Singh et al., 2009). The advantages of MAS based on biochemical and/or DNA/RNA variation include: (1) time

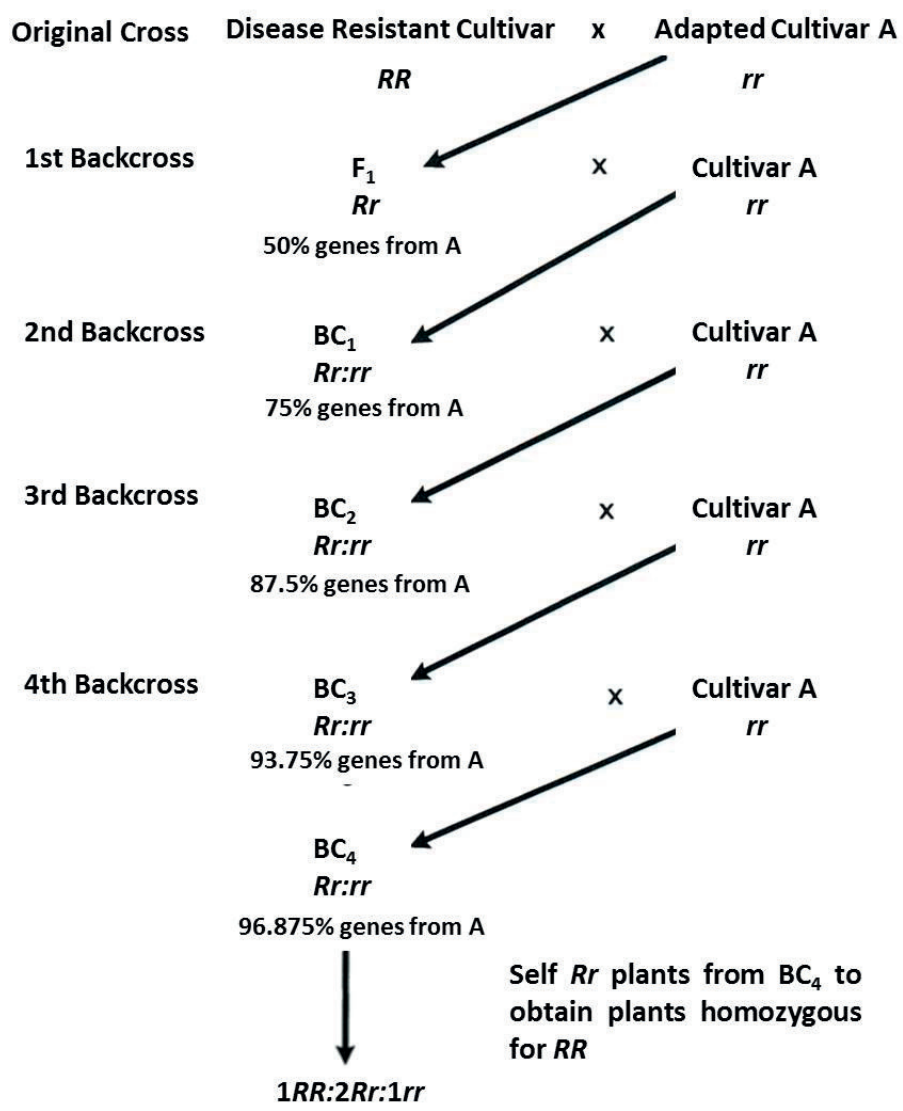

Figure 5. The backcross breeding method illustrated for a dominant allele for disease resistance $(R)$ from a resistant cultivar (donor or non-recurrent parent) that is transferred to a susceptible, adapted cultivar A (recurrent parent). The $R$ allele can be analogous to a high-yellowness PSY1 allele (the PSY1Ao allele and the $P S Y 1 B b$ allele) that is introgressed into a cultivar (recurrent parent) with very good agronomic and industrial characteristics, except for high GYPC (individuals carrying the PSY1Al allele and the PSY1Ba allele). Marker-assisted selection can be performed from BC $_{1}$ onwards (Sleper and Poehlman, 2006). 
savings from the substitution of complex field experiments with molecular tests, (2) elimination of unreliable phenotypic evaluation associated with environmental variation present in field trials, (3) selection of genotypes at the seedling stage, (4) gene 'pyramiding' or combining multiple genes at the same time, (5) avoiding the transfer of undesirable deleterious genes, (6) selection for traits with low heritability, and (7) testing for specific traits where phenotypic evaluation is not possible (i.e., quarantine restrictions may prevent the use of exotic pathogens for screening) (Collard et al., 2005).

\section{Conclusions}

Pasta color is partly determined by the intrinsic characteristics of the semolina from which it is made. In this sense, the yellow component of semolina is highly associated with GYPC, which mainly corresponds to carotenoids (especially in the form of trans-lutein). Pasta yellow color is also associated with the degradation of these pigments during grain milling and the pasta production process.

This review shows that the GYPC of nine Chilean genotypes of durum wheat is insufficient with respect to the values present in a group of international elite cultivars. The use of artificial coloring in pasta production is banned in several countries, which is an important limitation for local pasta production and potential exports. In agreement with the GYPC levels of the nine Chilean durum wheat genotypes studied, these materials carried the PSY1Al allele and the $P S Y 1 B a$ allele, which are associated with intermediate and low levels of GYPC, respectively. In summary, this evidence justifies ongoing and future breeding work in Chile for this particular trait; for example, work is currently being carried out by the PUC and INIA-Quilamapu to improve the grain quality of durum wheat. This project consists of characterizing the semolina yellowness of a durum wheat base population of 124 genotypes mainly from the CIMMYT and the INIA breeding programs. This work has also focused on the genotypic characterization of the PSY1A and PSYIB loci, which are appropriate candidate genes associated with GYPC based on the existing literature. One objective of the genotypic characterization is to identify the desired haplotype for its potential introduction into the national durum wheat breeding programs. This includes identifying individuals that contain the PSY1Ao and PSY1Bb alleles because these alleles were associated with high GYPC values in previous studies. Subsequently, these individuals will be used as donor parents, and the alleles conferring high GYPC will be introgressed into the Chilean durum wheat cultivars using backcrossing and marker-assisted selection to efficiently accelerate the improvement of semolina yellowness of those materials. Finally, other candidate genes or markers related to GYPC could be studied in the future, and their association with endosperm yellowness could be sought in the base population to obtain better estimates of the phenotypic values already characterized and to improve the semolina yellowness predictions for plant material not yet evaluated.

\section{Acknowledgments}

This work was financially supported by Conicyt (grant Fondecyt de Iniciación n¹1110066, 2011-2014). The authors thank Karen Campos and Nicolás Jiménez for their valuable help in the characterization of the PSY1A and PSYIB loci. 


\title{
Resumen
}

\begin{abstract}
A. Schulthess y A.R. Schwember. 2013. Mejora del contenido de pigmentos amarillos del grano de trigo candeal (Triticum turgidum $\mathrm{L}$. var durum) a través de fitomejoramiento. Cien Inv. Agr. 40(3): 475-490. El contenido de pigmentos amarillos del grano de trigo (GYPC) es un rasgo de calidad importante que determina la calidad de la pasta. El objetivo principal de esta revisión de literatura es examinar la regulación genética de la amarillez endospermática para mejorar el GYPC a través del fitomejoramiento, lo que finalmente se traduciría en una mejor calidad de la pasta. Aunque el GYPC es un rasgo poligénico, es un carácter altamente heredable, aspecto que ha facilitado el trabajo de mejoramiento a nivel internacional. El GYPC está controlado por uno o dos loci principales de efectos aditivos, además de varios genes menores, y existe evidencia que demuestra que los loci de la fitoeno sintasa PSY1A y PSY1B son los principales genes candidatos que regulan el GYPC. Nueve genotipos chilenos de trigo candeal (Triticum turgidum L. var. durum) mostraron niveles intermedio a bajos de GYPC basado en datos fenotípicos y genotípicos. El siguiente paso consistirá en incrementar el GYPC de estos materiales, introgresando las variantes alélicas de $P S Y 1$ de alta amarillez (es decir, el alelo PSY1Ao y el alelo PSY1Bb) a través de estrategias de fitomejoramiento como el retrocruzamiento y la selección asistida por marcadores moleculares.
\end{abstract}

Palabras clave: Color mejorado, contenido de pigmentos amarillos del grano, PSY1A, PSY1B, retrocruzamiento, selección asistida por marcadores, trigo candeal.

\section{References}

Blanco, A., M.P. Bellomo, A.Cenci, C. DeGiovanni, R. Dovidio, E. Iacono, B. Laddomada, M.A. Pagnotta, E. Porceddu, A. Sciancalepore, R. Simeone, and O.A.Tanzarella. 1998. A genetic linkage map of durum wheat. Theor. Appl. Genet. 97:721-728.

Blanco, A., P. Colasuonno, A. Gadaleta, G. Mangini, A. Schiavulli, R. Simeone, A.M. Digesù, P. De Vita, A.M. Mastrangelo, and L. Cattivelli. 2011. Quantitative trait loci for yellow pigment concentration and individual carotenoid compounds in durum wheat. J. Cereal Sci. 54:255-264.

Borrelli, G. M., A.M. De Leonardis, C. Platani, and A. Troccoli. 2008. Distribution along durum wheat kernel of the components involved in semolina colour. J. Cereal Sci. 48:494-502.

Borrelli, G. M., A.M. De Leonardis, C. Fares, C. Platani, and N. Di Fonzo. 2003. Effects of Modified Processing Conditions on Oxidative Properties of Semolina Dough and Pasta. Cereal Chem. 80: 225 - 231.

Briggs, F.N., and P.F. Knowles. 1967. Introduction to plant breeding. New Cork: Reinhold Publishing. p. 162-173.
Britton, G. 1998. Overview of carotenoid biosynthesis. In: Britton $\mathrm{G}$, Liaaen Jensen $\mathrm{S}$, Pfander $\mathrm{H}$. (eds.). Carotenoids. Birkhauser, Basel. p.13-147.

Buckner, B., T.L. Kelson, and D.S. Robertson. 1990. Cloning of the Y1 locus of maize, a gene involved in biosynthesis of carotenoids. Plant Cell 2:867-876.

Carrera, A., V. Echenique, W. Zhang, M. Helguera, F. Manthey, A. Schrager, A. Picca, G. Cervigni, and J. Dubcovsky. 2007. A deletion at the Lpx-B1 locus is associated with low lipoxygenase activity and improved pasta color in durum wheat (Triticum turgidum ssp. durum). J. Cereal Sci. 45:67-77.

Chander, S., Y. Guo, X. Yang, J. Zhang, X. Lu, J. Yan, T. Song, T. Rocheford T, and J. Li. 2008. Using molecular markers to identify two major loci controlling carotenoid contents in maize grain. Theor. Appl. Genet. 116:223-233.

Clarke, F.R., J.M. Clarke, T.N. McCaig, R.E. Knox, and R.M. DePauw. 2006. Inheritance of yellow pigment concentration in seven durum wheat crosses. Can. J. Plant Sci. 86:133-141.

Collard, B.C.Y., M.Z.Z. Jahufer, J.B. Brouwer, and E.C.K. Pang. 2005. An introduction to markers, 
quantitative trait loci (QTL) mapping and marker-assisted selection for crop improvement: The basic concepts. Euphytica 142:169-196.

Cuttriss, A.J., J.L. Mimica, C.A. Howitt, and B.J. Pogson. 2006. Carotenoids. In: Wise RR, Hoober J.K. (eds.). The structure and function of plastids. Springer, The Netherlands. p. 315-334.

DellaPenna, D., and B.J. Pogson. 2006. Vitamin synthesis in plants: tocopherols and carotenoids. Annu. Rev. Plant Biol. 57:711-738.

Demmig-Adams, B., and W.W.I. Adams. 1996. The role of xanthophylls cycle carotenoids in the protection of photosynthesis. Trends Plant Sci. 1:21-26.

Dexter, J. E., and B.A. Marchylo. 2000. Recent Trends in Durum Wheat Milling and Pasta Processing: Impact on Durum Wheat Quality Requirements. In: Proceedings of the international workshop on durum wheat, semolina, and pasta quality: recent achievements and new trends, Institute National de la Recherche Agronomique. Montpellier, France, 27 November 2000.

Dibari, B., F. Murat, A. Chosson, V. Gautier, C. Poncet, P. Lecomte, I. Mercier, H. Bergès, C. Pont, A. Blanco, and J. Salse. 2012. Deciphering the genomic structure, function and evolution of carotenogenesis related phytoene synthases in grasses. BMC Genomics 13:1-14.

Digesù, A. M., C. Platani, L. Cattivelli, G. Mangini, and A. Blanco. 2009. Genetic variability in yellow pigment components in cultivated and wild tetraploid wheats. J. Cereal Sci. 50:210-218.

Dogbo, O., A. Laferrière, A. D'Harlingue, and B. Camara. 1988. Carotenoid biosynthesis: Isolation and characterization of a bifunctional enzyme catalyzing the synthesis of phytoene. PNAS 85: 7054-7058.

Dubcovsky, J. 2004. Marker-Assisted Selection in Public Breeding Programs: The Wheat Experience. Crop Sci. 44:6.

Elouafi, I., N.M. Nachit, and L.M. Martin. 2001. Identification of a microsatellite on chromosome 7B showing a strong linkage with yellow pigment in durum wheat (Triticum turgidum L. var. durum). Hereditas 135:255-261.

Fehr, W.R. 1987. Principles of cultivar development: theory and technique, vol. 1, Macmillan Publishing. New York, USA. p. 360-376.
Feillet, P., J.C. Autran, and C. Icard-Vernière. 2000. Mini review: Pasta brownness: an assessment. J. Cereal Sci. 32:215-233.

Ficco, D.B.M., C. Riefolo, G. Nicastro, V. De Simone, A.M. Di Gesu, R. Beleggia, C. Platani, L. Cattivelli, and P. De Vita. 2009. Phytate and mineral elements concentration in a collection of Italian durum wheat cultivars. Field Crops Res. 111:235-242.

Fu, B.X. 2008. Asian noodles: history, classification, raw materials, and processing. Food Res. Int. 41:888-902.

Fu, Z., J. Yan, Y. Zheng, M. Warburton, J. Crouch, and J. Li. 2009. Nucleotide diversity and molecular evolution of the PSY1 gene in Zea mays compared to some other grass species. Theor. Appl. Genet. 120:709-720.

Gallagher, C.E., P.D. Matthews, F. Li, and E.T. Wurtzel. 2004. Gene duplication in the carotenoid biosynthetic pathway preceded evolution of the grasses. Plant Physiol. 135:1776-1783.

Gonzalez-Hernandez, J.L., E.M. Elias, and S.F. Kianian. 2004. Mapping genes for grain protein concentration and grain yield on chromosome 5B of Triticum turgidum (L.) var. dicoccoides. Euphytica 139:217-225.

Granado, F., B. Olmedilla, and I. Blanco. 2003. Review article: Nutritional and clinical relevance of lutein in human health. Br. J. Nutr. 90: 487-502.

Hable, W.E., K.K. Oishi, and K.S. Schumaker. 1998. Viviparous-5 encodes phytoene desaturase, an enzyme essential for abscisic acid (ABA) accumulation and seed development in maize. Mol. Gen. Genet. 257:167-176.

Hare, R. 2006. Agronomy of the durum wheats Kamilaroi, Yallaroi, Wollaroi and EGA Bellaroi. Profitable and Sustainable Primary Industries. NSW DPI. Primefact 140. p. 1-8. Available online at: http://www.dpi.nsw.gov.au/_data/assets/ pdf_file/0007/63646/Agronomy-of-the-durumwheats---Primefact-140-final.pdf (Website accessed: February 8, 2013).

Harjes, C.E., T.R. Rocheford, L. Bai, T.P. Brutnell, C.B. Kandianis, S.G. Sowinski, A.E. Stapleton, R. Vallabhaneni, M. Williams, E.T. Wurtzel, J. Yan, and E.S. Buckler. 2008. Natural genetic 
variation in lycopene epsilon cyclase tapped for maize biofortification. Science 319:330-333.

Harlan, J.R. 1995. The living fields - our agricultural heritage. Cambridge University Press, Cambridge.

He, X.Y., Z.H. He, W. Ma, R. Appels, and C.X. Xia. 2009a. Allelic variants of phytoene synthase 1 (Psyl) genes in Chinese and CIMMYT wheat cultivars and development of functional markers for flour colour. Mol. Breeding 23:553-563.

He, X., J. Wang, K. Ammar, R.J. Peña, X. Xia, and Z. He. 2009b. Allelic variants at the $P s y-A 1$ and $P s y-$ $B 1$ loci in durum wheat and their associations with grain yellowness. Crop Sci. 49:2058-2064.

He, Z.H., J. Yang, Y. Zhang, K. Quail, and R.J. Peña. 2004. Pan bread and dry white Chinese noodle qualities in Chinese winter wheats. Euphytica 139:257-267.

He, X.Y., Y.L. Zhang, Z.H. He, Y.P. Wu, Y.G. Xiao, C.X. Ma, and X.C. Xia. 2008. Characterization of phytoene synthase 1 gene (Psyl) located on common wheat chromosome 7A and development of a functional marker. Theor. Appl. Genet. 116:213-221.

Hentschel, V., K. Kranl, J. Hollmann, M.G. Lindhauer, V. Bohm, and R. Bitsch. 2002. Spectrophotometric determination of yellow pigment content and evaluation of carotenoids by high-performance liquid chromatography in durum wheat grain. J. Agr. Food Chem. 50:6663-6668.

Hirschberg, J. 2001. Carotenoid biosynthesis in flowering plants. Curr. Opin. Plant Biol. 4:210-218.

Howitt, C.A., C.R. Cavanagh, A.F. Bowerman, C. Cazzonelli, L. Rampling, J.L. Mimica, and B.J. Pogson. 2009. Alternative splicing, activation of cryptic exons and amino acid substitutions in carotenoid biosynthetic genes are associated with lutein accumulation in wheat endosperm. Funct. Integr. Genom. 9:363-376.

Howitt, C.A., and B.J. Pogson. 2006. Carotenoid accumulation and function in seeds and non-green tissues. Plant Cell Environ. 29:435-445.

Joppa, L.R., C. Du, G.E. Hart, and G.A. Hareland. 1997. Mapping a QTL for grain protein in tetraploid wheat (Triticum turgidum L.) using a population of recombinant inbred chromosome lines. Crop Sci. 37:1586-1589.
Kaneko, S., T. Nagamine, and T. Yamada. 1995. Esterification of endosperm lutein with fatty-acids during the storage of wheat seeds. Biosci. Biotech. Bioch. 59:1-4.

Kneipp, J., 2008. Durum wheat production report, first ed. NSW Department of Primary Industries, Orange, New South Wales, Australia.

Komugi, 2012. Catalogue of Gene Symbols. KOMUGI: Wheat Genetic Resources Database. Available online at: http://www.shigen.nig.ac.jp/ wheat/komugi/ (Website accessed: January 2, 2013).

Kruger, J.E., R.R. Matsuo, and K. Preston. 1992. A comparison of methods for the prediction of Cantonese noodle color. Can. J. Plant Sci. 72:1021-1029.

Kuchel, H., P. Langridge, L. Mosionek, K. Williams, and S.P. Jefferies. 2006. The genetic control of milling yield, dough rheology and baking quality of wheat. Theor. Appl. Genet. 112:1487-1495.

Landrum, J.T., and R.A. Bone. 2004. Dietery lutein and zeaxanthin: reducing the risk for macular degeneration. Agro Food Ind. Hi Tec. 15:22-25.

Li, F., C. Murillo, and E.T. Wurtzel. 2007. Maize Y9 encodes a product essential for 15-cis-\{zeta\}-carotene isomerization. Plant Physiol. 144:1181-1189.

Li, F., R. Vallabhaneni, J. Yu, T. Rocheford, and E.T. Wurtzel. 2008. The maize phytoene synthase gene family: Overlapping roles for carotenogenesis in endosperm, photomorphogenesis, and thermal stress tolerance. Plant Physiol. 147:1334-1346.

Lindgren, L.O., K.G. Stalberg, and A.S. Hoglund. 2003. Seed-specific overexpression of an endogenous Arabidopsis phytoene synthase gene results in delayed germination and increased levels of carotenoids, chlorophyll, and abscisic acid. Plant Physiol. 132:779-785.

Ma, W., G. Daggard, M. Sutherland, and P. Brennan. 1999. Molecular markers for quality attributes in wheat. In: P. Williamson, P. Banks, I. Haak, J. Thompson, and A. Campbell (eds.). Proceedings Assembly Wheat Breeding Society of Australia, $9^{\text {th }}$, Toowoomba, Queensland. Vol. 1. 27 Sept-1 Oct. 1999. Wheat Breeding Society of Australia. Toowoomba, Australia. p. 115-117. 
Mares, D.J., and A.W. Campbell. 2001. Mapping components of flour and noodle colour in Australian wheat. Aust. J. Agr. Res. 52:1297-1309.

Matthews, P.D., R.B. Luo, and E.T. Wurtzel. 2003. Maize phytoene desaturase and zeta-carotene desaturase catalyse a poly- $Z$ desaturation pathway: implications for genetic engineering of carotenoid content among cereal crops. J. Exp. Bot. 54:2215-2230.

Matus, I. 2007. Mejoramiento genético para rendimiento y calidad de trigo candeal en Chile. In: E. Acevedo and P. Silva (eds.). Trigo candeal: Calidad, Mercado y Zonas de Cultivo. Santiago, Universidad de Chile. Facultad de Ciencias Agronómicas, 2007-12-21 Serie Ciencias Agronómicas $\mathrm{N}^{\circ} 12$. p. 119-128.

Mellado, M. 2007. El trigo en Chile. Primera edición. Colección Libros INIA No ${ }^{\circ}$, Instituto de Investigaciones Agropecuarias, Centro Regional de Investigación Quilamapu. Chillán, Chile. 684 pp.

Michelmore, R.W. 1995. Molecular approaches to manipulation of disease resistance genes. Annu. Rev. Phytopatol. 15:393-427.

Nachit, M.M. 1992. Durum wheat breeding for Mediterranean dryland of North Africa and West Asia. In: Rajaram, S., Saari, E.E., Hettel, G.P. (eds.). Durum Wheats: Challenges and Oportunities. CIMMYT. Ciudad Obregon, Mexico. p.14-27.

Paine, J.A., C.A. Shipton, S. Chaggar, R.M. Howells, M.J. Kennedy, G. Vernon, S.Y. Wright, E. Hinchliffe, J.L Adams, A.L. Silverstone, and R. Drake. 2005. Improving the nutritional value of Golden Rice through increased pro-vitamin A content. Nat. Biotechnol. 23:482-487.

Palaisa, K.A., M. Morgante, M. Williams, and A. Rafalski. 2003. Contrasting effects of selection on sequence diversity and linkage disequilibrium at two phytoene synthase loci. Plant Cell 15:1795-1806.

Panfili, G., A. Fratianni, and M. Irano. 2004. Improved normal-phase high-performance liquid chromatography procedure for the determination of carotenoids in cereals. J. Agr. Food Chem. 52:6373-6377.

Parker, G.D., K.J. Chalmers, A.J. Rathjen, and P. Langridge. 1998. Mapping loci associated with flour color in wheat. Theor. Appl. Genet. 97:238-245.
Patil, R.M., M.D. Oak, S.A. Tamhankar, P. Sourdille, and V.S. Rao. 2008. Mapping and validation of a major QTL for yellow pigment content on 7AL in durum wheat (Triticum turgidum L. ssp. durum). Mol. Breeding 21:485-496.

Porceddu, E. 1995. Durum wheat quality in the Mediterranean countries. In: di Fonzo, N., Kaan, F., Nachit, M. (eds.). Durum wheat quality in the Mediterranean region, n. 22, Options Méditerranéennes. p.11-21.

Pozniak, C. J., J. M. Clarke, and F. R. Clarke. 2012. Potential for detection of marker-trait associations in durum wheat using unbalanced, historical phenotypic datasets. Mol. Breeding 30:1537-1550.

Pozniak, C.J., R.E. Knox, F.R. Clarke, and J.M. Clarke. 2007. Identification of QTL and association of a Phytoene synthase gene with endosperm colour in durum wheat. Theor. Appl. Genet. 114:525-537.

Qin, X.Q., W.J. Zhang, J. Dubcovsky, and L. Tian. 2012. Cloning and comparative analysis of carotenoid $\square$-hydroxylase genes provides new insights into carotenoid metabolism in tetraploid (Triticum turgidum ssp. durum) and hexaploid (Triticum aestivum) wheat grains. Plant Mol. Biol. 80:631-646.

Ramachandran, A., C. Pozniak, J. Clarke, and A. Singh. 2010. Carotenoid accumulation during grain development in durum wheat. J. Cereal Sci. 52:30-38.

Ravel, C., M. Dardevet, F. Leenhardt, J. Bordes, J.L. Joseph, M.R. Perretant, F. Exbrayat, C. Poncet, F. Balfourier, E. Chanliaud, and G. Charmet. 2013. Improving the yellow pigment content of bread wheat flour by selecting the three homeologous copies of Psy1. Mol. Breeding 31:87-99.

Ribaut, J.-M., X. Hu, D. Hoisington, and D. Gonzalez-de-Leon. 1997. Use of STSs and SSRs as rapid and reliable preselection tools in a markerassisted selection-backcross scheme. Plant Mol. Biol. Rep. 15:154-162.

Reimer, S., C.J. Pozniak, F.R. Clarke, J.M. Clarke, D.J. Sommers, R.E. Knox, and A.K. Singh. 2008. Association mapping of yellow pigment in an elite collection of durum wheat cultivars and breeding lines. Genome 51:1016-1025. 
Roncallo, P., G. Cervigni, C. Jensen, R. Miranda, A. Carrera, M. Helguera, and V. Echenique. 2012. QTL analysis of main and epistatic effects for flour color traits in durum wheat. Euphytica 185:77-92.

Sadeque, A., and M. Turner. 2010. QTL mapping of flour color in a hexaploid wheat doubled haploid population using diversity array technology. Thai J. Agric. Sci. 43: 103-108.

Schulthess, A. 2013. Factores genotípicos, ambientales y agronómicos que influencian la amarillez de semolina de trigo candeal en Chile. MS Thesis. Pontificia Universidad Católica de Chile. Santiago, Chile. 155 pp.

Schwember, A. 2012. Programas de mejoramiento genético: Fruta para el mundo. Agronomía y Forestal 44:9.

Shewry, P. 2009. Increasing the health benefits of wheat. FEBS Journal 276:71-71.

Singh, M., P.E. Lewis, K. Hardeman, L. Bai, J.K.C Rose, M. Mazourek, P. Chomet, and T.P. Brutnell. 2003. Activator mutagenesis of the pink scutellum1/viviparous7 locus of maize. Plant Cell 15:874-884.

Singh, A., S. Reimer, C.J. Pozniak, F.R. Clarke, J.M. Clarke, R.E. Knox, and A.K. Singh. 2009. Allelic variation at Psy1-A1 and association with yellow pigment in durum wheat grain. Theor. Appl. Genet. 118:1539-1548.

Sissons, M. 2008. Role of durum wheat composition on the quality of pasta and bread. Food 2: 75-90.

Sissons, M.J., N.E. Egan, and M.C. Gianibelli. 2005. New insights into the role of gluten on durum pasta quality using reconstitution method. Cereal Chem. 82:601-608.

Sleeper, D.A., and J.M. Poehlman. 2006. Breeding field crops. $5^{\text {th }}$ edition. Ames: Blackwell Pub Iowa. $424 \mathrm{pp}$.

Troccoli, A., G.M. Borrelli, P. De Vita, C. Fares, and N. Di Fonzo. 2000. Durum wheat quality: a multidisciplinary concept. J. Cereal Sci. 32:99-113.

Wang, J., X. He, Z. He, H. Wang, and X. Xia. 2009. Cloning and phylogenetic analysis of phytoene synthase 1 (Psy1) genes in common wheat and related species. Hereditas 146:208-256.

West, K.P., and I. Darnton-Hill. 2001. Vitamin A deficiency. In: R.D. Semba, and M.W. Bloem (eds.). Nutrition and Health in Developing Countries. Humana Press. Totowa, NJ, USA. p. 267-306.

Wong, J.C., R.J. Lambert, E.T. Wurtzel, and T.R. Rocheford. 2004. QTL and candidate genes phytoene synthase and zeta-carotene desaturase associated with the accumulation of carotenoids in maize. Theor. Appl. Genet. 108:349-359.

Yamamoto, H.Y., R.C. Bugos, and A.D. Hieber. 1999. Biochemistry and molecular biology of the xanthophyll cycle. In: Frank, H.A., A.J. Young, G. Britton, and R.J. Cogdell (eds.). The photochemistry of carotenoids. Kluwer. Dordrecht, The Netherlands. p. 293-303.

Ye, X.D., S. Al-Babili, A. Kloti, J. Zhang, P. Lucca, P. Beyer, and I. Potrykus. 2000. Engineering the provitamin A (beta-carotene) biosynthetic pathway into (carotenoid-free) rice endosperm. Science 287:303-305.

Yeum, K.J., and R.M. Russell. 2002. Carotenoid bioavailability and bioconversion. Annu. Rev. Nutr. 22:483-504.

Zhang, W., S. Chao, F. Manthey, O. Chicaiza, J.C. Brevis, V. Echenique, and J. Dubcovsky. 2008. QTL analysis of pasta quality using a composite microsatellite and SNP map of durum wheat. Theor. Appl. Genet. 117:1361-1377.

Zhang, C., C. Donga, X. He, L. Zhang, X. Xia, and Z. He. 2011. Allelic variants at the TaZds-D1 locus on wheat chromosome 2DL and their association with yellow pigment content. Crop Sci. 51:1580-1590.

Zhang, W., and J. Dubcovsky. 2008. Association between allelic variation at the Phytoene synthase 1 gene and yellow pigment content in the wheat grain. Theor. Appl. Genet. 116:635-645.

Zhang, Y.L., Y.P. Wu, Y.G. Xiao, Z.H. He, Y. Zhang, J. Yan, Y. Zhang, X.C. Xia, and C.X. Ma. 2009. QTL mapping for flour and noodle colour components and yellow pigment content in common wheat. Euphytica 165:435-444.

Zohary, D., and M. Hopf. 1993. Domestication of plants in the old World - The origin and spread of cultivated plants in West Asia, Europe, and the Nile Valley. Clarendon Press, Oxford. 